\title{
KERAGAMAN FENOTIPE DAN KEMIRIPAN MORFOLOGIS HANJELI (Coix lacryma-jobi L.) DI KABUPATEN LIMA PULUH KOTA
}

\author{
Ayu Kurnia Illahi ${ }^{1}$ \\ ${ }^{1}$ Politeknik Pertanian Negeri Payakumbuh, Sumatera Barat \\ * Corresponding Author: ayu10yurizal@gmail.com
}

\begin{abstract}
[PHENOTYPIC VARIABILITY AND MORPHOLOGICAL SIMILARITY OF JOB'S TEARS (Coix lacryma-jobi L.) IN LIMA PULUH KOTA REGENCY]. Job's tears (Coix lacryma-jobi L) Has been long known as alternatif food crop and spread over the West Sumatera Province. This study aims to determine the similarity of job's tears based on morphological characters. This research was conducted in eight sub districts in Lima Puluh Kota regency. The accessions were observed on the basis of purposive sampling method. Data were collected for 29 morphological characteristics and subjected to the similarity analysis and cluster analysis using NtSys Ver 2.02i. From the analysis of similarity, job's tears has a similarity coefficient ranging from 0.07 to 0.63 and shows a distant level of similarity to job's tears even though they are located close to each other, so that the level of similarity of 74 accessions varies and spreads irregularly.
\end{abstract}

Keyword: job's tears, variability, similarity coefficient

\begin{abstract}
ABSTRAK
Hanjeli merupakan tanaman pangan alternatif yang telah lama dikenal dan tersebar luas di di Provinsi Sumatera Barat. Penelitian ini bertujuan untuk mengetahui tingkat kemiripan anjeli berdasarkan karakter morfologi. Penelitian ini dilakukan pada delapan kecamatan di Kabupaten Lima Puluh Kota. Aksesi diamati berdasarkan metode sampling purposif. Data dikumpulkan dari 29 karakter morfologi dan diolah dengan analisis kemiripan dan analisis klaster menggunakan NtSys Ver 2.02i Berdasarkan analisis kemiripan, Aksesi hanjeli memiliki koefísien kemiripan berkisar 0.07-0.63 dan menunjukkan tingkat kemiripan hanjeli yang jauh walaupun berada pada lokasi yang berdekatan, sehingga tingkat kemiripan 74 aksesi bervariasi dan menyebar tidak beraturan.
\end{abstract}

Kata kunci: hanjeli, variabilitas, koefisien kemiripan 


\section{PENDAHULUAN}

Tanaman hanjeli dapat menjadi sebagai salah satu bahan pangan alternatif yang mudah dibudidayakan, tahan hama dan penyakit, toleran terhadap kekeringan dan kebanjiran, serta memiliki adaptasi luas pada berbagai kondisi lingkungan. Tanaman hanjeli telah banyak dibudidayakan dan dimanfaatkan pada derah Jawa Barat. Keberadaan tanaman hanjeli di luar pulau jawa tidak dimanfaatkan, hal ini dapat diamati dari kurangnya pengembangan tanaman hanjeli. Usaha pengembangan tanaman hanjeli merupakan alternatif untuk memenuhi kebutuhan pangan pada daerah yang memiliki jumlah penduduk yang banyak, salah satunya di Provinsi Sumatera Barat. Sumatera Barat memiliki wilayah yang luas dengan kondisi geografis yang berbeda-beda. Kabupaten Lima Puluh Kota adalah salah satu daerah di Provinsi Sumatera Barat yang memiliki kondisi geografis yang beragam. Topografi daerah Kabupaten Lima Puluh Kota bervariasi antara datar, bergelombang dan berbukit-bukit dengan ketinggian dari permukaan laut antara $110 \mathrm{~m}$ dan $2.261 \mathrm{~m}$.

Tanaman hanjeli memiliki karakteristik seperti rumput tegak, bercabang kuat, tingginya dapat mencapai 3 $\mathrm{m}$. Buluh terisi dengan empulur, bercabang pada bagian atasnya. Daun besar dan berpelepah, helaian daun memita sampai membundar telur-melanset, tepi daun kasar, halus atau kasap permukaan atasnya. Perbungaan di ketiak daun paling atas, soliter atau terdiri atas 2-7 berkas, putih atau kebiruan, mengandung 2 tandan; tandan betina mengandung buliran yang duduk, buliran dengan 1 floret, tandan jantan dengan kira-kira 10 buliran yang menyirap dan muncul berpasangan atau tiga-tiga, 1 mempunyai gantilan lainnya duduk; buliran melanset sampai menjorong, mengandung 1-2 floret jantan. Buah bervariasi dalam ukuran, bentuk, warna dan kekerasannya, biasanya berwarna abu-abu, kuning-merah tua atau keunguan, lunak atau keras, berisi jali. Jali berwarna merah tua untuk yang berkulit keras, atau merah muda untuk yang berkulit lunak (Prohati, 2016).

Semua informasi yang diperoleh dari hasil karakterisasi dan evaluasi merupakan modal untuk dipergunakan dalam kegiatan penyusunan program pemuliaan. Di samping itu juga merupakan upaya di dalam penyediaan bahan industri yang mempunyai nilai ekonomi tinggi (Astuti, 2004).

Tujuan dari penelitian ini adalah untuk mengetahui keragaman fenotipe dan kemiripan morfologis hanjeli (Coix lacryma-jobi L.) di Kabupaten Lima Puluh Kota. Informasi mengenai karakteristik tanaman hanjeli dan evaluasi kemiripan antar aksesi di Kabupaten Lima Puluh Kota perlu untuk diketahui, guna untuk menunjang kegiatan pemuliaan tanaman hanjeli selanjutnya.

\section{METODE PENELITIAN}

Penelitian dilaksanakan di Kabupaten Lima Puluh Kota. Setelah dilakukan eksplorasi, tanaman hanjeli ditemukan pada delapan kecamatan, yaitu Kecamatan Akabiluru, Kecamaran Harau, Kecamatan Kapur IX, Kecamatan Luhak, Kecamatan Mungka, Kecamatan Pangkalan, Kecamatan Payakumbuh, dan Kecamatan Situjuh. Informasi lokasi pengambilan aksesi disajikan pada Tabel 1.

Bahan pada penelitian ini adalah aksesi tanaman hanjeli yang telah memiliki tinggi tanaman $\geq 50 \mathrm{~cm}$. Alat yang dibutuhkan pada penelitian adalah jangka sorong, color chart, kuisioner, meteran, kantong plastik, kamera digital, kertas label, pisau, gunting, sabit, GPS (Global Pasitioning System) Map 76 CS x , mistar, tisu, dan alat tulis.

Penelitian ini menggunakan metode survei dengan pengambilan sampel secara sengaja (purpossive sampling). Jumlah aksesi pada penitian ini adalah 74 aksesi. Pengumpulan data sampel pada daerah terpilih dilakukan secara langsung tehadap tanaman hanjeli, karakter dan skor data hasil pengamatan disajikan pada Tabel 2. Data dari setiap sampel dianalisis secara statistik kemudian dibandingkan dengan sampel lainnya. Pada masing-masing sampel dilakukan pengamatan terhadap karakter fenotipik tanaman. Adapun karakter yang diamati yaitu karakter kuantitatif dan kualitatif batang, daun, bunga (jika ada), dan buah (jika ada).

Nilai varians fenotipik ditentukan sebagai berikut (Steel \& Torrie, 1995) :

$$
\sigma_{\mathrm{f}}^{2}=\frac{\sum \mathrm{Xi}^{2}-(\mathrm{x}) \sum(\mathrm{Xi})^{2}}{\mathrm{n}-1}
$$

Untuk menentukan standar deviasi diggunakan rumus :

$$
\operatorname{Sd}^{2} \mathrm{f}=\sqrt{\frac{6^{2} f}{n-1}}
$$

Keterangan :

$\sigma_{\mathrm{f}}^{2} \quad=$ Varians fenotipik

$\mathrm{X}_{\mathrm{i}} \quad=$ nilai rata-rata ke $\mathrm{i}$

$\mathrm{N}=$ jumlah nomor yang diuji

$\mathrm{Sd}^{2}{ }_{\mathrm{f}}=$ standar deviasi varian fenotipik

Pinaria (1995) menyatakan kriteria luas dan sempitnya variabilitas fenotipik yaitu :

Bila $\sigma_{\mathrm{f}}^{2} \geq 2 \mathrm{Sd}_{\mathrm{f}}^{2}=$ varian fenotipik luas

Bila $\sigma^{2} \mathrm{f}<2 \operatorname{Sd}^{2} \mathrm{f}=$ varian fenotipik sempit. 
Tabel 1. Informasi lokasi sampel tanaman hanjeli di Kabupaten Lima Puluh Kota

\begin{tabular}{|c|c|c|c|c|c|}
\hline Kecamatan & $\begin{array}{l}\text { Kode } \\
\text { Aksesi }\end{array}$ & $\begin{array}{l}\text { Jumlah } \\
\text { aksesi }\end{array}$ & $\begin{array}{c}\text { Ketinggian } \\
\text { (mdpl) }\end{array}$ & $\begin{array}{l}\text { Lintang } \\
\text { Selatan }\end{array}$ & Bujur Timur \\
\hline Akabiluru & $\mathrm{AKB} 1$ & 1 & $569 \mathrm{mdpl}$ & $00^{\circ} 15^{\prime} 50.5^{\prime \prime}$ & $100^{\circ} 34^{\prime} 36.0 \prime$ \\
\hline Akabiluru & AKB 2 & 1 & 619 mdpl & $00^{\circ} 15^{\prime} 33.7^{\prime \prime}$ & $100^{\circ} 33^{\prime} 33.9$ ' \\
\hline Akabiluru & AKB 3 & 4 & 612 mdpl & $00^{\circ} 15^{\prime} 27.7^{\prime \prime}$ & $100^{\circ} 33^{\prime} 28.8^{\prime \prime}$ \\
\hline Akabiluru & AKB 4 & 1 & 589 mdpl & $00^{\circ} 14^{\prime} 58.5^{\prime \prime}$ & $100^{\circ} 33^{\prime} 07.4$ ' \\
\hline Akabiluru & AKB 5 & 2 & 593 mdpl & $00^{\circ} 14^{\prime} 56.4 ”$ & $100^{\circ} 33^{\prime} 04.8^{\prime \prime}$ \\
\hline Akabiluru & AKB 6 & 1 & 559 mdpl & $00^{\circ} 13^{\prime} 01.6 "$ & $100^{\circ} 31^{\prime} 53.6 "$ \\
\hline Harau & HRU 1 & 1 & 515 mdpl & $00^{\circ} 07^{\prime} 12.2^{\prime \prime}$ & $100^{\circ} 39^{\prime} 01.4^{\prime \prime}$ \\
\hline Harau & HRU 2 & 1 & 517 mdpl & $00^{\circ} 06^{\prime} 47.2 ”$ & $100^{\circ} 38^{\prime} 47.2 "$ \\
\hline Harau & HRU 3 & 1 & 517 mdpl & $00^{\circ} 86^{\prime} 47.3 ”$ & $100^{\circ} 38^{\prime} 47.2^{\prime \prime}$ \\
\hline Harau & HRU 4 & 1 & 527 mdpl & $00^{\circ} 06^{\prime} 38.1 ”$ & $100^{\circ} 38^{\prime} 33.6^{\prime \prime}$ \\
\hline Harau & HRU 5 & 2 & 527 mdpl & $00^{\circ} 06^{\prime} 37.5^{\prime \prime}$ & $100^{\circ} 38^{\prime} 33.3 "$ \\
\hline Harau & HRU 6 & 1 & $520 \mathrm{mdpl}$ & $00^{\circ} 06^{\prime} 38.6^{\prime \prime}$ & $100^{\circ} 38^{\prime} 33.4^{\prime \prime}$ \\
\hline Harau & HRU 7 & 1 & 507 mdpl & $00^{\circ} 11^{\prime} 38.6 ”$ & $100^{\circ} 38^{\prime} 33.4^{\prime \prime}$ \\
\hline Harau & HRU 8 & 1 & 503 mdpl & $00^{\circ} 11^{\prime} 10.8^{\prime \prime}$ & $100^{\circ} 40^{\prime} 15.0 \prime$ \\
\hline Harau & HRU 9 & 1 & $512 \mathrm{mdpl}$ & $00^{\circ} 11 ' 10.4 ”$ & $100^{\circ} 40^{\prime} 14.6 "$ \\
\hline Harau & HRU 10 & 1 & 508 mdpl & $00^{\circ} 11^{\prime} 20.6 ”$ & $100^{\circ} 40^{\prime} 39.8 \prime$ \\
\hline Kapur IX & KPR 1 & 3 & 136 mdpl & $00^{\circ} 14^{\prime} 37.7 ”$ & $100^{\circ} 32 ’ 40.9 "$ \\
\hline Luhak & LHK 1 & 3 & 546 mdpl & $00^{\circ} 14^{\prime} 34.6 ”$ & $100^{\circ} 40^{\prime} 39.7$ \\
\hline Luhak & LHK 2 & 1 & 543 mdpl & $00^{\circ} 14^{\prime} 34.5^{\prime \prime}$ & $100^{\circ} 40^{\prime} 40.4 "$ \\
\hline Luhak & LHK 3 & 1 & 522 mdpl & $00^{\circ} 14^{\prime} 32.3 ”$ & $100^{\circ} 40^{\prime} 43.3 "$ \\
\hline Mungka & MGK 1 & 1 & 545 mdpl & $00^{\circ} 04^{\prime} 21.9 ”$ & $100^{\circ} 33^{\prime} 47.8^{\prime \prime}$ \\
\hline Mungka & MGK 2 & 4 & $551 \mathrm{mdpl}$ & $00^{\circ} 03^{\prime} 47.5^{\prime \prime}$ & $100^{\circ} 33^{\prime} 29.0$ '” \\
\hline Mungka & MGK 3 & 12 & 563 mdpl & $00^{\circ} 03^{\prime} 40.2^{\prime \prime}$ & $100^{\circ} 33^{\prime} 15.0^{\prime \prime}$ \\
\hline Pangkalan & PKL 1 & 1 & 138 mdpl & $00^{\circ} 02^{\prime} 44.3^{\prime \prime}$ & $100^{\circ} 45^{\prime} 22.1^{\prime \prime}$ \\
\hline Pangkalan & PKL 2 & 6 & 114 mdpl & $00^{\circ} 02^{\prime} 45.0^{\prime \prime}$ & $100^{\circ} 45^{\prime} 21.9 ”$ \\
\hline Pangkalan & PKL 3 & 3 & 116 mdpl & $00^{\circ} 04^{\prime} 32.6^{\prime \prime}$ & $100^{\circ} 41^{\prime} 53.2 "$ \\
\hline Payakumbuh & PYK 1 & 1 & 513 mdpl & $00^{\circ} 10^{\prime} 34.4^{\prime \prime}$ & $100^{\circ} 36^{\prime} 30.3 \prime$ \\
\hline Payakumbuh & PYK 2 & 1 & 519 mdpl & $00^{\circ} 04^{\prime} 32.6 "$ & $100^{\circ} 41^{\prime} 53.2 "$ \\
\hline Payakumbuh & PYK 3 & 1 & 515 mdpl & $00^{\circ} 10^{\prime} 13.1 ”$ & $100^{\circ} 36^{\prime} 14.7 "$ \\
\hline Payakumbuh & PYK 4 & 1 & 527 mdpl & $00^{\circ} 10^{\prime} 14.2^{\prime \prime}$ & $100^{\circ} 36^{\prime} 16.0 "$ \\
\hline Payakumbuh & PYK 5 & 2 & 517 mdpl & $00^{\circ} 10^{\prime} 14.0^{\prime \prime}$ & $100^{\circ} 36^{\prime} 16.0 "$ \\
\hline Payakumbuh & PYK 6 & 1 & 503 mdpl & $00^{\circ} 10^{\prime} 37.4 "$ & $100^{\circ} 36^{\prime} 44.2^{\prime \prime}$ \\
\hline Payakumbuh & PYK 7 & 3 & 524 mdpl & $00^{\circ} 10^{\prime} 59.5 "$ & $100^{\circ} 37^{\prime} 21.3 "$ \\
\hline Payakumbuh & PYK 8 & 1 & 515 mdpl & $00^{\circ} 10^{\prime} 31.1 ”$ & $100^{\circ} 36^{\prime} 25.2^{\prime \prime}$ \\
\hline Payakumbuh & PYK 9 & 1 & 522 mdpl & $00^{\circ} 10^{\prime} 31.1 "$ & $100^{\circ} 36^{\prime} 24.4^{\prime \prime}$ \\
\hline Situjuh & STJ 1 & 4 & 559 mdpl & $00^{\circ} 16^{\prime} 56.6^{\prime \prime}$ & $100^{\circ} 36^{\prime} 26.6^{\prime \prime}$ \\
\hline Situjuh & STJ 2 & 1 & 612 mdpl & $00^{\circ} 17^{\prime} 21.7^{\prime \prime}$ & $100^{\circ} 35^{\prime} 28.1^{\prime \prime}$ \\
\hline Situjuh & STJ 3 & 1 & $605 \mathrm{mdpl}$ & $00^{\circ} 17^{\prime} 12.0^{\prime \prime}$ & $100^{\circ} 35^{\prime} 32.6^{\prime \prime}$ \\
\hline \multicolumn{2}{|c|}{ Total Aksesi } & & & & 74 \\
\hline
\end{tabular}


Tabel 2. Karakter dan skor serta deskripsi masingmasing kategori sifat pengamatan karakter morfologi tanaman hanjeli di Kabupaten Lima Puluh Kota

\begin{tabular}{|c|c|c|c|}
\hline No. & Karakter & Skor & $\begin{array}{c}\text { Deskripsi Kategori } \\
\text { Sifat }\end{array}$ \\
\hline \multirow[t]{3}{*}{1.} & $\begin{array}{l}\text { Bentuk } \\
\text { batang }\end{array}$ & 1 & bulat(teres) \\
\hline & & 3 & bersegi (angularis) \\
\hline & & 5 & pipih \\
\hline \multirow[t]{4}{*}{2.} & $\begin{array}{l}\text { Permukaan } \\
\text { batang }\end{array}$ & 1 & licin \\
\hline & & 3 & berusuk \\
\hline & & 5 & beralur \\
\hline & & 7 & bersayap \\
\hline \multirow[t]{3}{*}{3.} & $\begin{array}{l}\text { Warna kulit } \\
\text { batang }\end{array}$ & 1 & hijau tua \\
\hline & & 3 & hijau muda \\
\hline & & 5 & hijau kekuningan \\
\hline \multirow[t]{6}{*}{4.} & $\begin{array}{l}\text { Arah tum- } \\
\text { buh batang }\end{array}$ & 1 & tegak \\
\hline & & 3 & condong \\
\hline & & 5 & ke atas \\
\hline & & 7 & mendatar \\
\hline & & 9 & menggantung \\
\hline & & 11 & berbaring \\
\hline \multirow[t]{3}{*}{5.} & $\begin{array}{l}\text { Warna ruas } \\
\text { batang }\end{array}$ & 1 & hijau tua \\
\hline & & 3 & hijau muda \\
\hline & & 5 & hijau kekuningan \\
\hline \multirow[t]{3}{*}{6.} & $\begin{array}{l}\text { Warna no- } \\
\text { dus }\end{array}$ & 1 & hijau tua \\
\hline & & 3 & hijau muda \\
\hline & & 5 & hijau kekuningan \\
\hline \multirow[t]{2}{*}{7.} & Tipe daun & 1 & lengkap \\
\hline & & 3 & tidak lengkap \\
\hline \multirow[t]{5}{*}{8.} & $\begin{array}{l}\text { Bangun } \\
\text { daun }\end{array}$ & 1 & bangun garis \\
\hline & & 3 & bangun pita \\
\hline & & 5 & bangun pedang \\
\hline & & 7 & bangun paku \\
\hline & & 9 & bangun jarum \\
\hline
\end{tabular}

tabel lanjutan

9. Bentuk

$\begin{array}{lcl}\text { Bentuk } & 1 & \text { runcing } \\ \text { ujung daun } & 3 & \text { meruncing } \\ & 5 & \text { tumpul } \\ 7 & \text { membulat } \\ & 9 & \text { rompang } \\ & 11 & \text { terbelah }\end{array}$

10

$$
\begin{aligned}
& \text { Pertulangan } \\
& \text { daun }
\end{aligned}
$$

3 menjari

5 melengkung

7 sejajar

11. Tepi daun 1 rata (integer)

3 bertoreh (divisus)

Tekstur

12. permukaan 1 licin

daun

3 gundul

5 kasap

7 berkerut

9 berbingkul-bingkul

11 berbulu

13 berbulu halus dan rapat

15 berbulu kasar

17 bersisik

13. Warna helai 1 hijau tua
daun

3 hijau muda

5 hijau kekuningan

Bentuk

14. pangkal 1 runcing daun

$\begin{array}{lcl}3 & \text { meruncing } \\ 5 & \text { tumpul } \\ 7 & \text { membulat } \\ 9 & \begin{array}{l}\text { rompang } \\ \text { berlekuk }\end{array} \\ & 11 & \text { hijau tua } \\ \text { 15. Warna } & 1 & \begin{array}{l}\text { pucuk mu- } \\ \text { da }\end{array} \\ & 3 & \begin{array}{l}\text { hijau muda } \\ \text { hijau kekuningan }\end{array}\end{array}$


tabel lanjutan

16. Susunan dain

1

3

Warna per-

17. mukaan atas

daun

Warna per-

18. mukaan bawah daun

Keadaan per-

19. mukaan atas daun

Keadaan per-

20. mukaan bawah daun

21. Warna tulang daun

2. Warna tangkai bunga

23. Tata letak bunga

24. Warna anther

\begin{tabular}{lll} 
& 3 & kuning \\
5 & kuning kecoklatan \\
25. Warna stigma & 1 & hijau tua \\
& 3 & hijau muda \\
& 5 & hijau kekuningan \\
& 1 & merata \\
26. Pematangan & 3 & tidak merata \\
\hline
\end{tabular}

Analisis kemiripan bertujuan untuk mengetahui tingkat kemiripan antara sampel tanaman hanjeli yang didapatkan di lapangan. Data karakter morfologi tanaman hanjeli yang didapat diolah secara staatistik menggunakan program perhitungan statistik yaitu NTSYSpc 2.02i. Hasil dari analisis kemiripan ditampilkan dalam bentuk dendogram yang akan menggambarkan hubungan kemiripan antar aksesi tanaman berdasarkan karakter morfologinya.

\section{HASIL DAN PEMBAHASAN}

Hasil pengamatan dan pengukuran terhadap morfologi tanaman hanjeli yang berada di delapan kecamatan pada Kabupaten Lima Puluh Kota, data hasil pengamatan dan pengukuran penampilan fenotipik tanaman hanjeli dapat dilihat pada Tabel 3. Nilai variabilitas fenotipik pada karakter bentuk batang, permukaan batang, arah tumbuh batang, warna ruas batang, warna nodus, tipe daun, bangun daun, bentuk ujung daun, pertulangan daun, tepi daun, tekstur permukaan, warna helaian, bentuk pangkal, warna pucuk muda, susunan daun, warna permukaan atas, warna permukaan bawah, keadaan permukaan atas, keadaan permukaan bawah dan warna tulang daun memiliki nilai yang sempit. Hal ini menandakan karakter kualitatif memiliki nilai variabilitas fenotipik yang sempit. Nilai variabilitas fenotipik pada karakter lingkar batang, tinggi tanaman, panjang helaian, lebar helaian, jarak antar helaian, panjang pelepah, jumlah anakan total dan jumlah anakan produktif memiliki nilai variabilitas fenotipik yang luas.

Hasil analisis kemiripan hubungan antar 74 aksesi hanjeli di Kabupaten Lima Puluh Kota digambarkan dalam bentuk dendogram pada Gambar 1. Pada gambar tersebut dapat diamati koefisien kemiripan semua aksesi hanjeli ini berada di antara 0,07-0,63. Angka koefisien akan mengambarkan tingkat kemiripan di antara aksesi yang dibandingkan. Pada dendogram nilai koefisien yang semakin besar akan menunjukkan tingkat kemiripan dari aksesi yang dibandingkan akan semakin dekat, sedangkan tingkat kemiripan dari setiap aksesi yang dibandingkan akan semakin kecil dapat diketahui apabila nilai koefisien kemiripannya memberikan nilai yang kecil (Fauza, 2015). Kemiripan dikatakan jauh apabila kurang dari 0,6 atau 60\% (Cahrani et al., 2004). Individu yang berkerabat dekat akan mempunyai jarak genetik yang dekat, sedangkan bila berkerabat jauh akan mempunyai jarak genetik yang jauh (Lee, 1998). Ahmad et al. (1980) melaporkan bahwa genotipe yang berasal dari daerah yang sama tidak selalu berada dalam klaster yang sama, artinya diversitas geografi tidak selalu ada hubungannya dengan diversitas genetik(Daradjat et al., 1991).

Aksesi hanjeli PKL terlihat memiliki tingkat kemiripan yang dekat karena terletakberdekatan pada setiap aksesi. Hal ini diasumsikan bahwa pada sampel PKL, setiap sampelnya memiliki tingkat kekerabatan yang dekat. 
Tabel 3. Data variabilitas fenotipik tanaman hanjeli di delapan kecamatan Kabupaten Lima Puluh Kota

\begin{tabular}{|c|c|c|c|c|c|}
\hline No Karakter & Kisaran & Rata-rata & $\sigma_{f}^{2}$ & $\mathrm{sd}^{2} \mathrm{t}$ & Kriteria \\
\hline $\begin{array}{l}\text { Bentuk } \\
\text { batang }\end{array}$ & Bulat & Bulat & $\infty$ & $\infty$ & Sempit \\
\hline $\begin{array}{l}\text { Lingkar } \\
\text { 2. batang } \\
(\mathrm{mm})\end{array}$ & $3.23-14.78$ & 7.65 & 7.35 & 2.71 & Luas \\
\hline $\begin{array}{l}\text { Per- } \\
\text { mukaan }\end{array}$ & Licin & Licin & $\infty$ & $\infty$ & Sempit \\
\hline $\begin{array}{l}\text { Warna } \\
\text { 4. kulit ba- } \\
\text { tang }\end{array}$ & $\begin{array}{l}\text { Hijau tua- } \\
\text { hijau } \\
\text { kekuningan }\end{array}$ & $\begin{array}{l}\text { Hijau } \\
\text { muda }\end{array}$ & 1.11 & 1.06 & Sempit \\
\hline $\begin{array}{l}\text { Arah tum- } \\
\text { buh btang }\end{array}$ & Tegak & Tegak & $\infty$ & $\infty$ & Sempit \\
\hline $\begin{array}{l}\text { Warna } \\
\text { 6. ruas ba- } \\
\text { tang }\end{array}$ & $\begin{array}{l}\text { Hijau tua- } \\
\text { hijau } \\
\text { kekuningan }\end{array}$ & $\begin{array}{l}\text { Hijau } \\
\text { muda }\end{array}$ & 0.87 & 0.93 & Sempit \\
\hline $\begin{array}{l}\text { 7. Warna } \\
\text { nodus }\end{array}$ & $\begin{array}{l}\text { Hijau tua- } \\
\text { hijau muda }\end{array}$ & Hijau tua & 0.30 & 0.55 & Sempit \\
\hline $\begin{array}{l}\text { Tinggi } \\
\text { 8. tanaman } \\
(\mathrm{cm})\end{array}$ & $\begin{array}{l}70.67- \\
239.00\end{array}$ & 141.35 & $\begin{array}{c}1290 . \\
90\end{array}$ & 35.93 & Luas \\
\hline 9. Tipe daun & Lengkap & Lengkap & $\infty$ & $\infty$ & Sempit \\
\hline $\begin{array}{l}\text { 10. Bangun } \\
\text { daun }\end{array}$ & Pita & Pita & $\infty$ & $\infty$ & Sempit \\
\hline $\begin{array}{l}\text { Bentuk } \\
\text { 11. ujung } \\
\text { daun }\end{array}$ & Meruncing & $\begin{array}{l}\text { Meruncin } \\
\mathrm{g}\end{array}$ & $\infty$ & $\infty$ & Sempit \\
\hline $\begin{array}{l}\text { Pertulan- } \\
\text { gan daun }\end{array}$ & Sejajar & Sejajar & $\infty$ & $\infty$ & Sempit \\
\hline 13. Tepi daun & Rata & Rata & $\infty$ & $\infty$ & Sempit \\
\hline 14. $\begin{array}{l}\text { Tekstur } \\
\text { permukan }\end{array}$ & $\begin{array}{l}\text { Berbulu } \\
\text { halus dan } \\
\text { rapat }\end{array}$ & $\begin{array}{l}\text { Berbulu } \\
\text { halus dan } \\
\text { rapat }\end{array}$ & $\infty$ & $\infty$ & Sempit \\
\hline $\begin{array}{l}\text { Panjang } \\
\text { helaian }\end{array}$ & $\begin{array}{l}26.20- \\
85.93\end{array}$ & 44.03 & $\begin{array}{c}168.3 \\
8\end{array}$ & 12.98 & Luas \\
\hline $\begin{array}{l}\text { Warna } \\
\text { helai daun }\end{array}$ & $\begin{array}{l}\text { Hijau tua- } \\
\text { hijau muda }\end{array}$ & Hijau tua & 0.11 & 0.33 & Sempit \\
\hline $\begin{array}{l}\text { Lebar } \\
\text { 17. helai daun } \\
\text { (cm) }\end{array}$ & $2.07-6.17$ & 3.50 & 0.56 & 0.75 & Sempit \\
\hline 18. $\begin{array}{l}\text { Bentuk } \\
\text { pangkal }\end{array}$ & Rompang & Rompang & $\infty$ & $\infty$ & Sempit \\
\hline $\begin{array}{l}\text { Jarak an- } \\
\text { 19. tar helaian } \\
\text { (cm) }\end{array}$ & $8.30-33.10$ & 19.30 & 26.28 & 5.13 & Luas \\
\hline
\end{tabular}

\section{tabel lanjutan}

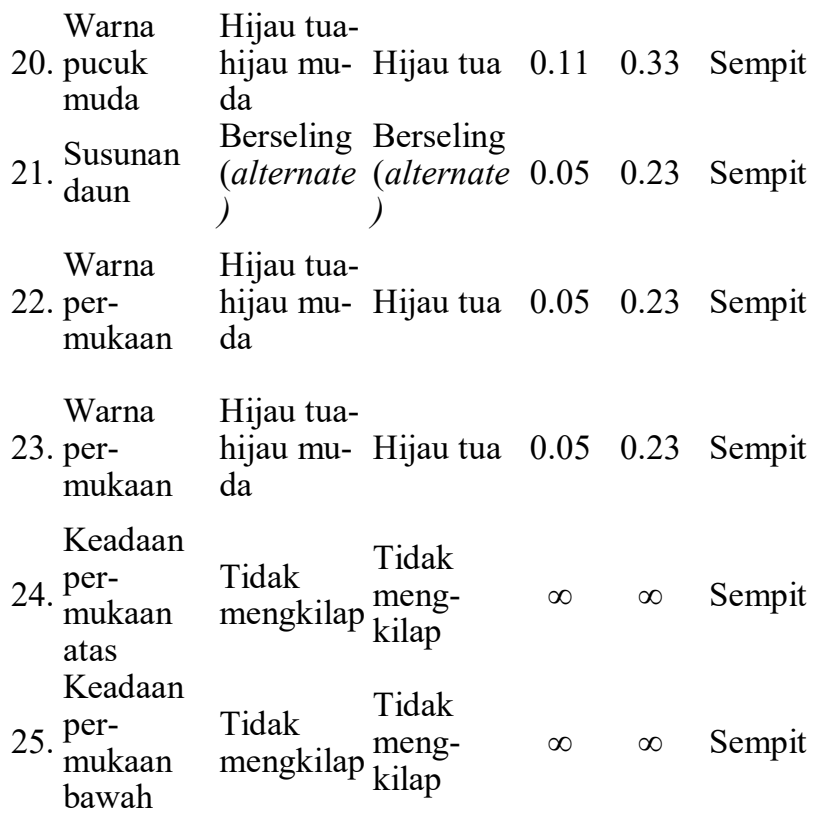
Warna Hijau tua-

\begin{tabular}{|c|c|c|c|c|c|}
\hline $\begin{array}{l}\text { Warna } \\
\text { daun }\end{array}$ & $\begin{array}{l}\text { hijau } \\
\text { kekuninga } \\
\mathrm{n}\end{array}$ & $\begin{array}{l}\text { Hijau } \\
\text { muda }\end{array}$ & 1.19 & 1.09 & Sempit \\
\hline $\begin{array}{l}\text { Panjang } \\
\text { pelepah }\end{array}$ & $\begin{array}{l}3.67- \\
18.40\end{array}$ & 7.77 & 7.93 & 2.82 & Luas \\
\hline $\begin{array}{l}\text { Jumlah } \\
\text { anakan }\end{array}$ & $4-68$ & 22.21 & $\begin{array}{c}199.5 \\
6\end{array}$ & $\begin{array}{c}14.1 \\
3\end{array}$ & Luas \\
\hline $\begin{array}{l}\text { Jumlah } \\
\text { 9. anakan } \\
\text { produktif }\end{array}$ & $2-65$ & 14.28 & $\begin{array}{c}129.3 \\
4\end{array}$ & $\begin{array}{c}11.3 \\
7\end{array}$ & Luas \\
\hline
\end{tabular}

Gambar dendogram karaker fenotipik 74 aksesi tanaman hanjeli ini dapat diketahui pada tingkat kemiripan 0,07 semua aksesi mengelompok menjadi dua kelompok. Pada kelompok pertama terdiri dari 73 aksesi, sedangkan pada kelompok kedua hanya terdiri dari 1 aksesi, yaitu LHK 1.3 yang mengelompok karena berbeda pada karakter warna helaian daun, tinggi tanaman, panjang helaian, jarak antar helaian, dan panjang pelepah.

Koefisien 0.314 aksesi mengelompok menjadi dua, yaitu pada kelompok IIA terdiri dari 72 aksesi sedangkan pada kelompok IIB terdapat 1 aksesi yang mengelompok karena perbedan pada pengamatan karakter kuantitatif yaitu tinggi tanaman, panjang helaian, lebar helaian daun, jarak antar helaian, dan panjang pelepah.

Tingkat kemiripan 0.63 terdapat dua aksesi yang mengelompok berdekatan yaitu aksesi HRU 3 dan MGK 3.11 yang memiliki hasil pengamatan yang sama pada beberapa karakter.

Jarak taksonomi merupakan angka-angka koefisien yang secara kuantitatif menggambarkan tingkat tidak miripan di antara sampel yang dibandingkan. Semakin 
besar nilai angka ketidakmiripan, maka semakin kecil tingkat kemiripan antara individu (bervariasi). Sebaliknya semakin kecil nilai ketidakmiripannya, maka semakin besar tingkat kemiripan di antara dua individu (variabilitas lebih sempit). Nilai koefisien ketidakmiripan di antara dua individu yang sama adalah nol (Fauza, 2008).



Gambar 1. Dendogram 74 sampel tanaman hanjeli pada delapan kecamatan berdasarkan karakter fenotipiknya. $\mathrm{AKB}=$ Akabiluru ; HRU = Harau ; KPR = Kapur IX; LHK = Luhak ; MGK = Mungka $;$ PKL = Pangkalan ; PYK = Payakumbuh ; STJ = Situjuh ; 1,2,3,4,5 = banyaknya sampel pada masing-masing lokasi

\section{KESIMPULAN}

Variabilitas fenotipik tanaman hanjeli pada karakter kulitatif memiliki nilai yang sempit, sedangkan pada karakter kuantitatif memiliki nilai variabilitas fenotipik yang luas. Analisis kemiripan fenotipik tanaman hanjeli untuk semua karakter memiliki nilai koefisien kemiripan berkisar antara 0.07-0.63. Pada koefisien 0.07 aksesi mengelompok menjadi dua kelompok yang menandakan tingkat kemiripan antar aksesi kecil, sedangkan pada nilai koefisien 0.63 terdapat dua aksesi yang mengelompok dan berdekatan yang menandakan tingkat kemiripan akan semakin dekat.

Saran yang dapat diberikan adalah dapat dilakukan penelitian lebih lanjut terhadap keberadaan tanaman hanjeli dan dapat dilakukan penelitian mengenai pengujian secara molekuler terhadap tingkat kekerabatan tanaman hanjeli.

\section{DAFTAR PUSTAKA}

Astuti, S.R.(2004). Eksplorasi Plasma Nutfah Tanaman pangan di Provinsi Kalimantan Barat. Balai Besar Penelitian dan Pengembangan Bioteknologi dan Sumberdaya Genetika Pertanian, Bogor.

Cahyarini, R.D., Yunus, A., Purwanto, E. (2004). Identifikasi keragaman genetik beberapa varietas lokal kedelai di Jawa berdasarkan analisis Isozim. Agrosains, 6 (2), 79-83.

Daradjat, A.A., Noch, M. \& Danakusuma, M.T. (1991). Diversitas genetik pada beberapa sifat kuantitatif tanaman Terigu (Triticum aestivium L.). Zuriat, 2(1), 21-25.

Fauza, H. (2009). Identifikasi Karakteristik Gambir (Uncaria spp.) di Sumatera Barat dan Analisis RAPD. Disertasi. Fakultas Pertanian Universitas Padjadjaran, Bandung.

Fauza, H. (2015). Studi awal penampilan fenotipik plasma nutfah jengkol (Pithecollobium jiringa) di Padang, Sumatera Barat. Pros. Seminar Nasional Masyarakat BIODIV INDON., 1(1), 23-30, Maret 2015.

Karuniawan, A., Wicaksono, H.N., Ustari, D., Setiawati, T. \& Supriatun, T. (2017). Identifikasi keragaman genetik plasma nutfah ubi kayu liar (Manihot glaziovii muell) berdasarkan karakter morfo-agronomi. Kultivasi, 16(3), 435-443. DOI: https://10.24198/kltv.v16i3. 14038.

Lee, M. (1998). DNA Markers for Detecting Genetic Realtionship among Germplasm Revealed for Establishing Heterotic Groups. Presented at The Maize Training Course, CIMMYT, Texcoco, Mexico, August 25, 1998.

Lesta, Mustikarini, E. D., Prayoga, G.I. (2018). Keragaman plasma nutfah pisang (Musa sp) di Pulau Bangka berdasarkan karakter morfologi. Agrosainstek, 2(1), 22-30.

Lestari, J. (2014). Kajian tentang Kadar Katekin Tanaman Gambir (Uncaria gambir Roxb.) Ditinjau dari Aspek Ketinggian Tempat dan Genetik. Skripsi. Fakultas Pertanian. Universitas Andalas, Padang.

Prohati, (2016). Keanekaragaman Hayati Tumbuhan. http://www.proseanet.org. 19 Januari 2016.

Swasti, E. (2007). Pengantar Pemuliaan Tanaman. Fakultas Pertanian, Universitas Andalas, Padang. 